\title{
Fatty Acid Profile of Blood Plasma at Mating and Early Gestation in Rabbit
}

\author{
Imane Hadjadj ${ }^{1}$, Anna-Katharina Hankele ${ }^{2}$, Eva Armero ${ }^{3}$ (D) , María-José Argente ${ }^{1}$ (D) \\ and María de la Luz García 1,*(D) \\ 1 Centro de Investigación e Innovación Agroalimentaria y Agroambiental (CIAGRO-UMH), \\ Miguel Hernández University, Ctra. de Beniel km 3,2., 03312 Orihuela, Spain; \\ imane.hadjadj@alu.umh.es (I.H.); mj.argente@umh.es (M.-J.A.) \\ 2 ETH Zurich, Animal Physiology, Institute of Agricultural Sciences, Universitaetstr. 2, \\ 8092 Zurich, Switzerland; anna-katharina.hankele@usys.ethz.ch \\ 3 Department of Agronomic Engineering, Technical University of Cartagena, Paseo Alfonso XIII 48, \\ 30203 Cartagena, Spain; eva.armero@upct.es \\ * Correspondence: mariluz.garcia@umh.es; Tel.: +34-96-6749-709
}

Citation: Hadjadj, I.; Hankele, A.-K.; Armero, E.; Argente, M.-J.; de la Luz García, M. Fatty Acid Profile of Blood Plasma at Mating and Early Gestation in Rabbit. Animals 2021, 11, 3200. https://doi.org/10.3390/ani11113200

Academic Editor: Johnny Roughan

Received: 14 October 2021

Accepted: 8 November 2021

Published: 9 November 2021

Publisher's Note: MDPI stays neutral with regard to jurisdictional claims in published maps and institutional affiliations.

Copyright: (c) 2021 by the authors. Licensee MDPI, Basel, Switzerland. This article is an open access article distributed under the terms and conditions of the Creative Commons Attribution (CC BY) license (https:// creativecommons.org/licenses/by/ $4.0 /)$.
Simple Summary: Fatty acids can be used as an energy substrate by oocytes and embryos. Ovulation rate and normal preimplantation embryos are limiting factors to increased litter size in rabbits. Knowledge of the fatty acid profile in blood plasma at mating and in early gestation and its relationship with the ovulation rate and early embryonic development can help improve doe productivity. In our study, palmitic, linoleic, oleic and stearic acids show the highest concentrations. Moreover, monounsaturated fatty acids are correlated with ovulation rate and normal embryos. The more SFA, the greater the embryonic development. This study could be useful for designing enriched feeds in animal production and for embryological studies, as the rabbit is an experimental model.

Abstract: The aim of this study was to analyse the fatty acid (FA) profile of blood plasma at mating and $72 \mathrm{hpm}$ by gas chromatography. Moreover, the correlation between FA and ovulation rate, normal embryos and compacted morulae was estimated. Palmitic, linoleic, oleic and stearic were the highest FA concentrations at mating and $72 \mathrm{hpm}$. Most long chain saturated and PUFA were higher at $72 \mathrm{hpm}$ than at mating, while MUFA were higher at mating. SFA, MUFA and PUFA were high and positively correlated. Correlation was 0.643 between MUFA at mating and ovulation rate, and 0.781 between MUFA and normal embryos, respectively. Compacted morulae were slightly correlated with SFA at mating (0.465). In conclusion, the FA profile of plasma varies depending on the reproductive cycle of the rabbit female, adapting to energetic requirements at mating and early gestation. Moreover, positive correlations are found between fatty acids and ovulation rate and embryo development and quality.

Keywords: embryo; MUFA; ovulation; PUFA; SFA

\section{Introduction}

From ovulation to implantation, oocytes and embryos are supported by maternal secretions from the oviduct and uterus (cow [1], sheep [2], murine [3], horse [4], sow [5] and rabbit [6]). The oviductal and uterine fluids mainly originate from blood filtrates [7] and secretions of endometrial luminal and glandular epithelial cells [8]. Thus, a complex milieu containing proteins, amino acids, carbohydrates and fatty acids (FA) is constituted to maintain embryo viability.

Fatty acids represent compact reserves of stored energy for oocytes and embryos [9]. Additionally, FA play a crucial role in modifying the physical properties and functions of biological membranes, and have potential effects on oocyte growth and maturation and embryo development and transport through reproductive traits [10-12]. The ability for the 
exogenous uptake of FA by the embryo has been demonstrated in several studies [13-15]. Specifically, rabbit embryos can already absorb FA at zygote stage [13], and it is reported that exogenously supplied fatty acids are beneficial for growth and development in cultivated oocytes and embryos [10]. Moreover, FA enriched diets consumed around the fertilization period and the first days of pregnancy and conditions in the oviductal and uterine environment [14] can affect embryo quality [15]. Rabbit is a livestock species reared for the production of hair, skin or meat and also as an experimental reference for other species, such as pigs or humans [16]. A detailed understanding of how ovulation rate and early embryo survival and development are affected by the FA profile could improve the productivity of rabbit females and further basic knowledge as an experimental model. Therefore, the aim of this work was to study the fatty acid profile at mating and in early gestation and its relationship with ovulation rate and embryo quality and development in rabbits.

\section{Materials and Methods}

\subsection{Experiment Animals and Design}

A total of 15 non-lactating multiparous rabbit females were used. Does were 9-10 months of age. Females belonged to two lines selected divergently by litter size variability [17]. Females were kept on the experimental farm at the Universidad Miguel Hernández de Elche (Spain). They were reared in individual cages and fed ad libitum with a commercial diet (crude protein, $17.5 \%$; crude fibre, $15.5 \%$; ether extract, $5.4 \%$; ash, $8.1 \%$ ) during their reproductive life.

\subsection{Blood Sampling}

Females that had finished their fourth lactation were weighed and mated. Following the blood sampling procedure described in [18], two blood samples of $3 \mathrm{~mL}$ were drawn from the central artery of each doe's ear at mating and $72 \mathrm{~h}$ post-mating (hpm). The blood sample was collected into a tube with tripotassium ethylenediaminetetraacetic acid (K3-EDTA). All samples were immediately centrifuged at $4000 \times g \mathrm{rpm}$ for $15 \mathrm{~min}$, and plasma was stored at $-80{ }^{\circ} \mathrm{C}$ until required for lipid analyses.

\subsection{Reproductive Traits}

At $72 \mathrm{hpm}$, females were euthanized by intravenous administration of sodium thiopental in a dose of $50 \mathrm{mg} / \mathrm{kg}$ of body weight (Thiobarbital, B. Braun Medical S.A., Barcelona, Spain). The entire reproductive tract was immediately removed in order to measure reproductive traits.

Total ovulation rate (OR) was estimated as the number of corpora lutea. Total embryos were recovered by perfusion of oviducts and uterine horns with $10 \mathrm{~mL}$ of Dulbecco's phosphate-buffered saline containing $0.2 \%$ of BSA. Embryos were classified as normal embryos (NE) when they presented homogeneous cellular mass and intact embryo coat, using a binocular stereoscopy microscope (Leica Mz $9.5 ; \times 600)$. Embryos were classified as early morulae or compacted morulae. Compacted morulae (CM) were expressed as percentage of NE.

\subsection{Fatty Acid Analyses}

All samples were analysed in duplicate. A $200 \mu \mathrm{L}$ sample of plasma was taken in a screw cap glass tube. One milliliter of $0.5 \mathrm{M} \mathrm{NaOH}$-methanol was added to each sample and the sample was boiled at $90^{\circ} \mathrm{C}$ for $15 \mathrm{~min}$. The sample was cooled in an ice bath to room temperature, $2 \mathrm{~mL}$ of BF3-methanol was added, and the sample was boiled at $90{ }^{\circ} \mathrm{C}$ for $20 \mathrm{~s}$. The sample was again cooled in an ice bath to room temperature, $1 \mathrm{~mL}$ of isooctane was added, and the mixture was shaken. In the measurement of recovery ratio of the internal standard, $1 \mathrm{~mL}$ iso-octane containing 0.05 mg 13:0 ME and 0.01 mg 19:0 ME was added. Five milliliters of saturated $\mathrm{NaCl}$ solution was then added, and the mixture was centrifuged at $4000 \times \mathrm{g} \mathrm{rpm}$ for $10 \mathrm{~min}$ at $4{ }^{\circ} \mathrm{C}$. When the iso-octane layer separated 
from the aqueous lower phase, the iso-octane layer was transferred to a glass vial. After iso-octane was evaporated under a stream of nitrogen gas, $250 \mu \mathrm{L}$ of hexane was added, and the sample was injected into the GC system. The fatty acids were measured using a gas chromatograph (GC-17A, Shimadzu, Kyoto, Japan) coupled with a flame ionization detector (FID) equipped with a capillary column (CP Sil $88100 \mathrm{~m} \times 0.25 \mathrm{~mm}$ i.d., $0.20 \mu \mathrm{m}$ film thickness; Agilent technologies, Madrid, Spain). The carrier gas was helium (flow $1.2 \mathrm{~mL} / \mathrm{min}$ ) with a split injection of 1:1. The temperature profiles were as follows: initial temperature, $45^{\circ} \mathrm{C}$ for $4 \mathrm{~min}$; heating first rate, $13^{\circ} \mathrm{C} / \mathrm{min}$ until $175^{\circ} \mathrm{C}(27 \mathrm{~min}$ isolation) and a second rate, $4{ }^{\circ} \mathrm{C}$ until $215^{\circ} \mathrm{C}\left(30 \mathrm{~min}\right.$ isolation); injector temperature, $250{ }^{\circ} \mathrm{C}$; and detector temperature, $260^{\circ} \mathrm{C}$. The fatty acids were identified by comparing the retention times with those of Fame Standard Mix (CRM47885, Sigma Aldrich, St. Louis, MA, USA).

\subsection{Statistical Analyses}

The model for analyzing FA profile included the effects of moment (two levels: at mating and at $72 \mathrm{hpm}$ ), line, random effect of female and weight of female as covariate.

All analyses were performed using Bayesian methodology [19]. Bounded uniform priors were used for all effects with the exception of the female effect, which was considered normally distributed, with mean 0 and variance $\mathrm{I} \sigma_{f}^{2}$, where I is a unity matrix, and $\sigma_{f}^{2}$ is the variance of the female effect. Female and residual effects were considered to be independent. Residuals were a priori normally distributed, with mean 0 and variance $\mathrm{I} \sigma_{e}^{2}$. The priors for the variances were also bounded uniform. Features of the marginal posterior distributions for all unknowns were estimated using Gibbs sampling. The Rabbit program developed by the Institute for Animal Science and Technology (Valencia, Spain) was used for all procedures. We used a chain of 60,000 samples, with a burn-in period of 10,000. Only one out of every 10 samples was saved for inferences. Convergence was tested using Geweke's $\mathrm{Z}$ criterion and Monte Carlo sampling errors were computed using time-series procedures.

Residual correlations between FA at mating and at $72 \mathrm{hpm}$ after correction by line and weight of female were estimated. A principal component analysis was carried out. These analyses were performed using the SAS statistical package.

\section{Results}

Table 1 shows the features of the marginal posterior distributions of the difference between FA profile measured at mating and at $72 \mathrm{hpm}$. A total of 31 different FA were identified in blood plasma, and three FA were not detected (octanoic, cis-10 pentadecanoic and adrenic acid). The highest FA concentrations at mating and at $72 \mathrm{hpm}$ were palmitic $(425.01 \mathrm{ng} / \mathrm{mL})$, linoleic $(408.00 \mathrm{ng} / \mathrm{mL})$, cis-9 oleic $(385.30 \mathrm{ng} / \mathrm{mL})$ and stearic $(238.08 \mathrm{ng} / \mathrm{mL})$, while palmitoleic $(29.31 \mathrm{ng} / \mathrm{mL})$, heptadecanoic $(21.26 \mathrm{ng} / \mathrm{mL})$, $\alpha$-linolenic $(13.77 \mathrm{ng} / \mathrm{mL})$, trans-9 elaidic $(13.41 \mathrm{ng} / \mathrm{mL})$, myristic $(12.91 \mathrm{ng} / \mathrm{mL})$ and pentadecanoic $(12.28 \mathrm{ng} / \mathrm{mL})$ were in lower concentration.

Short and medium chain FA were shown in very low concentrations and similar concentrations were found at mating and at $72 \mathrm{hpm}$. Only lauric was higher at mating than at $72 \mathrm{hpm}(\mathrm{D}=+0.39 \mathrm{ng} / \mathrm{mL} ; p>0.80)$.

Most long chain fatty acids were higher at $72 \mathrm{hpm}$ than at mating. Myristic, pentadecanoic, arachidic, heneicosanoic, behenic and tricosylic increased their concentration in this period. Conversely, heptadecanoic and lignoceric were higher at mating than at $72 \mathrm{hpm}$. Similar concentrations were found for palmitic, stearic and SFA between both moments.

Monounsaturated FA (MUFA) were higher at mating than $72 \mathrm{hpm}(\mathrm{D}=+55.75 \mathrm{ng} / \mathrm{mL}$; $p>0.80$ ). The increases ranged from $8 \%$ to $54 \%$ for myristoleic, trans- 9 elaidic, cis- 9 oleic, palmitoleic and cis-10 heptadecanoic.

Polyunsaturated FA (PUFA) showed a relevant lower concentration at mating than at $72 \mathrm{hpm}(\mathrm{D}=-30.67 \mathrm{ng} / \mathrm{mL}, p>0.90)$. Specifically, these PUFA were linolelaidic $(\mathrm{D}=-1.26 \mathrm{ng} / \mathrm{mL})$, linoleaic $(\mathrm{D}=-21.70 \mathrm{ng} / \mathrm{mL}), \alpha$-Linolenic $(\mathrm{D}=-4.61 \mathrm{ng} / \mathrm{mL})$, cis11,14 eicosadienoic $(\mathrm{D}=-1.41 \mathrm{ng} / \mathrm{mL})$ and arachidonic $(\mathrm{D}=-1.09 \mathrm{ng} / \mathrm{mL})$. Only $\gamma-$ 
Linolenic was higher at mating, while similar concentrations were found for cis-11,14,17 eicosatrienoic and cis-4,7,10,13,16,19 docohexaenoic.

Table 1. Means of the estimated marginal posterior distribution of the differences between mating and at $72 \mathrm{hpm}$ for fatty acid profile (D).

\begin{tabular}{|c|c|c|c|}
\hline Pathway & Biochemical Name & $\begin{array}{l}\text { Means } \\
(\mathrm{ng} / \mathrm{mL})\end{array}$ & $\underset{(\mathrm{ng} / \mathrm{mL})}{\mathrm{D}}$ \\
\hline \multirow{2}{*}{$\begin{array}{l}\text { Short chain fatty } \\
\text { acids }\end{array}$} & Butyric (C4:0) & 0.42 & +0.08 \\
\hline & Hexanoic (C6:0) & 0.02 & +0.00 \\
\hline \multirow{4}{*}{$\begin{array}{l}\text { Medium chain } \\
\text { fatty acids }\end{array}$} & Octanoic (C8:0) & ND & \\
\hline & Decanoic (C10:0) & 0.30 & +0.06 \\
\hline & Undecanoic (C11:0) & 0.45 & +0.09 \\
\hline & Lauric (C12:0) & 1.84 & +0.39 \\
\hline \multirow{11}{*}{$\begin{array}{l}\text { Long chain fatty } \\
\text { acids }\end{array}$} & Myristic (C14:0) & 12.91 & -5.57 \\
\hline & Pentadecanoic (C15:0) & 12.28 & -1.04 \\
\hline & Palmitic (C16:0) & 425.01 & +4.80 \\
\hline & Heptadecanoic (C17:0) & 21.26 & +2.14 \\
\hline & Stearic (C18:0) & 238.08 & -5.19 \\
\hline & Arachidic (C20:0) & 3.50 & -0.76 \\
\hline & Heneicosanoic (C21:0) & 2.12 & -0.98 \\
\hline & Behenic (C22:0) & 5.08 & -2.05 \\
\hline & Tricosylic (C23:0) & 8.09 & -5.55 \\
\hline & Lignoceric (C24:0) & 0.85 & +0.61 \\
\hline & $\Sigma$ SFA & 733.96 & -14.61 \\
\hline \multirow{10}{*}{$\begin{array}{l}\text { Monounsaturated } \\
\text { fatty acids }\end{array}$} & Myristoleic (C14:1c9) & 2.63 & +0.80 \\
\hline & $\begin{array}{l}\text { Cis-10 pentadecenoic } \\
\text { (C15:1c10) }\end{array}$ & ND & \\
\hline & Trans-9 elaidic (C18:1t9) & 13.41 & +5.75 \\
\hline & Cis-9 oleic (C18:1c9) & 385.30 & +32.13 \\
\hline & Palmitoleic (C16:1c9) & 29.31 & +8.75 \\
\hline & $\begin{array}{l}\text { Cis-10 heptadecenoic } \\
\text { (C17:1c10) }\end{array}$ & 5.91 & +2.22 \\
\hline & $\begin{array}{l}\text { Cis-11 eicosenoic } \\
\quad \text { (C20:1c11) }\end{array}$ & 4.04 & +0.41 \\
\hline & Erucic (C22:1c13) & 0.25 & +0.07 \\
\hline & Nervonic (C24:1c15) & 2.17 & +0.42 \\
\hline & $\Sigma$ MUFA & 445.07 & +55.75 \\
\hline \multirow{10}{*}{$\begin{array}{l}\text { Polyunsaturated } \\
\text { fatty acids }\end{array}$} & Linolelaidic (C18:2t9t12) & 3.14 & -1.26 \\
\hline & Linoleic (C18:2c9c12) & 408.00 & -21.70 \\
\hline & $\gamma$-Linolenic (C18:3c6c9c12) & 2.23 & +0.81 \\
\hline & $\begin{array}{c}\alpha \text {-Linolenic } \\
(\mathrm{C} 18: 3 \mathrm{c} 9 \mathrm{c} 12 \mathrm{c} 15)\end{array}$ & 13.77 & -4.61 \\
\hline & $\begin{array}{c}\text { Cis-11,14 eicosadienoic } \\
\text { (C20:2) }\end{array}$ & 6.65 & -1.41 \\
\hline & $\begin{array}{c}\text { Cis-11,14,17 eicosatrienoic } \\
\text { (C20:3) }\end{array}$ & 4.14 & +0.84 \\
\hline & $\begin{array}{l}\text { Arachidonic } \\
\text { (C20:4c5c8c11c14) }\end{array}$ & 1.61 & -1.09 \\
\hline & $\begin{array}{c}\text { Cis-4,7,10,13,16,19 } \\
\text { docosahexaenoic } \\
\text { (C22:6c4c7c10c13c16c19) }\end{array}$ & 0.77 & +0.02 \\
\hline & Adrenic (C22:4c7c10c13c16) & ND & \\
\hline & इPUFA & 440.76 & -30.67 \\
\hline
\end{tabular}


The correlations between FA at mating and at $72 \mathrm{hpm}$ and reproductive traits are presented in Table 2. Moreover, a principal component analysis was performed (Figure 1). The first three principal components explained $83 \%$ of total variation $(53 \%, 18 \%$ and $12 \%$, respectively). The predominant variables defining the first principal component were SFA, MUFA and PUFA both at mating and at $72 \mathrm{hpm}$, except for MUFA measured at mating. They were far from the origin and close to the axis. Thus, high and positive correlations were found between them, ranging from 0.492 to 0.899 . These correlations were significant, except for MUFA at mating and PUFA at $72 \mathrm{hpm}$ (Table 2).

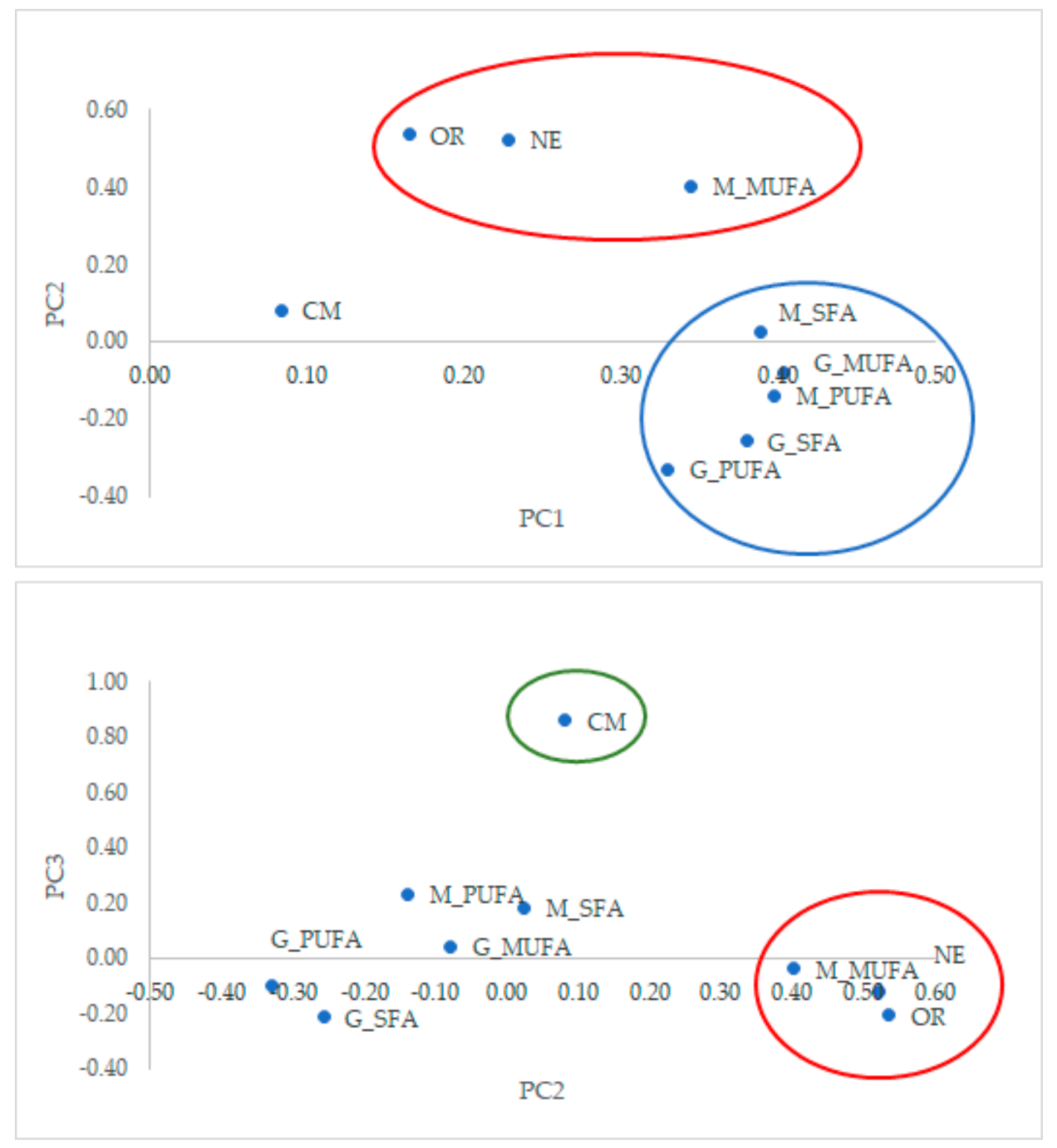

Figure 1. Projection of the traits in the plane defined by the 1st and 2nd principal component (PC) and the 2nd and 3rd PC. Variables of the 1st, 2nd and 3rd PC are surrounded by a blue, red and green circle, respectively. M_SFA: saturated fatty acid (FA) at mating; M_MUFA: monounsaturated FA at mating; M_PUFA: polyunsaturated FA at mating; G_SFA: saturated FA at 72 hpm; G_MUFA: monounsaturated FA at 72 hpm; G_PUFA: polyunsaturated FA at 72 hpm; OR: ovulation rate; NE: normal embryos; CM: compacted morulae. 
Table 2. Correlations for saturated fatty acid (SFA), monounsaturated fatty acid (MUFA), polyunsaturated fatty acid measured at mating and at $72 \mathrm{~h}$ post-mating, ovulation rate (OR), normal embryos (NE) and compacted morulae (CM).

\begin{tabular}{|c|c|c|c|c|c|c|c|c|c|}
\hline & & \multicolumn{2}{|c|}{ Mating } & \multicolumn{3}{|c|}{$72 \mathrm{hpc}$} & \multirow[b]{2}{*}{ OR } & \multirow[b]{2}{*}{ NE } & \multirow[b]{2}{*}{ MC } \\
\hline & & MUFA & PUFA & SFA & MUFA & PUFA & & & \\
\hline \multirow{3}{*}{ Mating } & SFA & $0.675^{*}$ & $0.899 *$ & $0.813 *$ & $0.808^{*}$ & 0.543 * & 0.267 & 0.268 & $0.465^{+}$ \\
\hline & MUFA & & $0.605 *$ & $0.492^{+}$ & $0.721 *$ & 0.342 & 0.643 * & $0.781 *$ & 0.169 \\
\hline & PUFA & & & 0.807 * & 0.861 * & 0.740 * & 0.123 & 0.341 & 0.328 \\
\hline \multirow{5}{*}{72 hpc } & SFA & & & & $0.826^{*}$ & 0.773 * & 0.092 & 0.267 & -0.123 \\
\hline & MUFA & & & & & $0.727^{*}$ & 0.275 & 0.334 & 0.183 \\
\hline & PUFA & & & & & & 0.108 & 0.092 & 0.050 \\
\hline & OR & & & & & & & 0.630 * & 0.027 \\
\hline & $\mathrm{NE}$ & & & & & & & & 0.047 \\
\hline
\end{tabular}

${ }^{*}$ Significant at level $0.05 ;^{+}$significant at level 0.10 .

Ovulation rate, normal embryos and MUFA at mating were located near the second principal component and close to each other (Figure 1). Thus, correlation between ovulation rate and normal embryos was 0.630 . Correlation was 0.643 between MUFA at mating and ovulation rate, and 0.781 between MUFA and normal embryos, respectively $(p<0.05)$.

Compacted morulae are the predominant variable defining the third principal component. Compacted morulae were slightly correlated with SFA at mating (0.465), and uncorrelated with the other FA.

\section{Discussion}

The results of this study provide a detailed FA profile at mating, when ovulation takes place and in early gestation. Palmitic, linoleic, oleic and stearic acid are the highest FA concentrations at mating and $72 \mathrm{hpm}$. It has been reported that oleic, palmitic and linoleic are capable of supporting growth of one-cell rabbit embryos to viable morulae [10], as these FA may serve as a storage pool of metabolic precursors presented in oviductal and uterine fluids and embryos [20].

As expected, arachidonic acid was found in lower concentration at $72 \mathrm{hpm}$. Arachidonic acid is a crucial precursor of prostaglandins [8], which are found in low concentration in the first days of pregnancy due to their luteolytic action [21,22].

The absence or low concentration of short and medium FA, docohexaenoic and adrenic acid agrees with the findings of other studies [23].

The FA profile is different at mating than at $72 \mathrm{hpm}$. MUFA concentration is higher at mating, while PUFA is in higher concentration at $72 \mathrm{hpm}$. MUFA are mainly used by follicle components as primary energy sources (see review in [24]), whereas PUFA are nutritionally essential for embryo development [20]. High quality oocytes exhibit high levels of oleic acid (in cows, [25]). The PUFA concentrations, especially linoleic acid, are high not only in plasma but also in oviductal fluid and embryos [20]. PUFA in general, and linolenic acid in particular, support essential development processes in mammalian embryos [26]. Linoleic acid acts as a precursor for eicosanoids and regulates the processes of endocytosis or exocytosis, ion channel modulation, DNA polymerase inhibition and gene expression [27]. Moreover, linoleic acid stimulates protein kinase $C$, which is necessary for cell differentiation and growth $[28,29]$. In mammals, the absence of enzymes to introduce double bonds at carbon atoms beyond C-9 in FA chains determines linoleic acid as essential FA because they are not able to synthesize it. Thus, it must be included in the diet [30]. In this sense, rabbit females can increase deposition of PUFA in the periovarian adipose tissue after a long-term dietary supplementation with fish oil. This deposition could favour the PUFA accessibility to their ovarian structures as corpora lutea, whose activity, measured by the progesterone production, is increased during embryo preimplantation period [31].

To the best of our knowledge, this is the first time that the correlation between FA profile at mating and $72 \mathrm{hpm}$ and ovulation rate and normal embryo and development have been studied. Ovulation rate and number of normal embryos are positively correlated 
with MUFA at mating. Moreover, the correlation between the percentage of compact morulae and SFA is slightly positive. Overlap of different embryo developmental stages is commonly observed [32] and could be related to the duration of ovulation or the oviductal and uterine fluid compositions [33]. Early morulae and compacted morulae can be found at $72 \mathrm{hpm}$. Palmitic acid, as the main SFA, was identified in abundant concentrations in more developed embryos [27] and is reported to be essential for FA elongation and desaturation in embryo development [34]. Moreover, incubation with palmitic acid showed that embryos can oxidize palmitic acid even at the single-cell stage, with subsequent increases, particularly from four-cell embryos onwards [20].

The results obtained in fatty acid composition could add useful knowledge of ovulation and early embryo metabolism. These data may also be useful practically in helping to develop non-destructive tests of oocyte and embryo quality and in improving culture media, cryopreservation and the success of IVF treatment.

\section{Conclusions}

The fatty acid profile of plasma varies depending on the reproductive cycle of the rabbit female, adapting to energy requirements at mating and in early gestation. In addition, correlations are found between fatty acids and ovulation rate and embryonic development and quality.

Author Contributions: Conceptualization, M.d.l.L.G., E.A. and M.-J.A.; methodology, M.d.l.L.G. and M.-J.A.; formal analysis, I.H., M.d.l.L.G.; data curation, I.H., M.d.l.L.G.; writing—original draft preparation, M.d.l.L.G.; writing—review and editing, I.H., A.-K.H., E.A., M.-J.A.; funding acquisition, M.d.l.L.G. All authors have read and agreed to the published version of the manuscript.

Funding: This research was funded by Valencia Regional Government, grant number AICO/2019/169. María de la Luz García was supported by postdoctoral grant, number BEST/2019, from Valencia Regional Government.

Institutional Review Board Statement: All experimental procedures were approved by the Miguel Hernández University of Elche Research Ethics Committee, according to Council Directives 98/58/EC and 2010/63/EU (reference number 2019/VSC/PEA/0017).

Informed Consent Statement: Not applicable.

Data Availability Statement: Data are available upon request to the corresponding author.

Acknowledgments: We thank our technician, Raquel Muelas, for the technical support.

Conflicts of Interest: The authors declare no conflict of interest.

\section{References}

1. Groebner, A.E.; Rubio-Aliaga, I.; Schulke, K.; Reichenbach, H.D.; Daniel, H.; Wolf, E.; Meyer, H.H.D.; Ulbrich, S.E. Increase of essential amino acids in the bovine uterine lumen during preimplantation development. Reproduction 2011, 141, 685-695. [CrossRef] [PubMed]

2. Gao, H.; Wu, G.; Spencer, T.E.; Johnson, G.A.; Li, X.; Bazer, F.W. Select nutrients in the ovine uterine lumen. I. Amino acids, glucose, and ions in uterine lumenal flushings of cyclic and pregnant ewes. Biol. Reprod. 2009, 80, 86-93. [CrossRef] [PubMed]

3. Harris, S.E.; Gopichandran, N.; Picton, H.M.; Leese, H.J.; Orsi, N. Nutrient concentrations in murine follicular fluid and the female reproductive tract. Theriogenology 2005, 64, 992-1006. [CrossRef] [PubMed]

4. Drews, B.; Milojevic, V.; Giller, K.; Ulbrich, S. Fatty acid profile of blood plasma and oviduct and uterine fluid during early and late luteal phase in the horse. Theriogenology 2018, 114, 258-265. [CrossRef] [PubMed]

5. Iritani, A.; Sato, E.; Nishikawa, Y. Secretion rates and chemical composition of oviduct and uterine fluids in sows. J. Anim. Sci. 1974, 39, 582-588. [CrossRef] [PubMed]

6. Beier, H.M. Oviductal and uterine fluids. J. Reprod. Fertil. 1974, 37, 221-237. [CrossRef]

7. Oliphant, G.; Reynolds, A.B.; Smith, P.F.; Ross, P.R.; Marta, J.S. Immunocytochemical localization and determination of hormoneinduced synthesis of the sulfated oviductal glycoproteins. Biol. Reprod. 1984, 31, 165-174. [CrossRef]

8. Aguilar, J.; Reyley, M. The uterine tubal fluid: Secretion, composition and biological effects. Anim. Reprod. 2005, 2, 91-105.

9. Sturmey, R.; Reis, A.; Leese, H.; McEvoy, T. Role of fatty acids in energy provision during oocyte maturation and early embryo development. Reprod. Domest. Anim. 2009, 44, 50-58. [CrossRef] 
10. Kane, M. Fatty acids as energy sources for culture of one-cell rabbit ova to viable morulae. Biol. Reprod. 1979, 20, 323-332. [CrossRef]

11. Stubbs, C.D.; Smith, A.D. The modification of mammalian membrane polyunsaturated fatty acid composition in relation to membrane fluidity and function. Biochim. Biophys. Acta BBA Rev. Biomembr. 1984, 779, 89-137. [CrossRef]

12. Warzych, E.; Lipinska, P. Energy metabolism of follicular environment during oocyte growth and maturation. J. Reprod. Dev. 2020, 66, 1-7. [CrossRef] [PubMed]

13. Waterman, R.A.; Wall, R.J. Lipid interactions with in vitro development of mammalian zygotes. Gamete Res. 1988, $21,243-254$. [CrossRef] [PubMed]

14. Ashworth, C.J.; Toma, L.M.; Hunter, M.G. Nutritional effects on oocyte and embryo development in mammals: Implications for reproductive efficiency and environmental sustainability. Philos. Trans. R. Soc. B Biol. Sci. 2009, 364, 3351-3361. [CrossRef]

15. Rodríguez, M.; García-García, R.; Arias-Álvarez, M.; Millán, P.; Febrel, N.; Formoso-Rafferty, N.; López-Tello, J.; Lorenzo, P.; Rebollar, P. Improvements in the conception rate, milk composition and embryo quality of rabbit does after dietary enrichment with n-3 polyunsaturated fatty acids. Animal 2018, 12, 2080-2088. [CrossRef]

16. García, M.-L.; Argente, M.-J. The genetic improvement in meat rabbits. Lagomorpha Charact. Work. Title 2020, 5, 1-18. [CrossRef]

17. Argente, M.J.; García, M.L.; Zbyňovská, K.; Petruška, P.; Capcarova, M.; Blasco, A. Correlated response to selection for litter size environmental variability in rabbits' resilience. Animal 2019, 13, 2348-2355. [CrossRef]

18. Beloumi, D.; Blasco, A.; Muelas, R.; Santacreu, M.A.; García, M.D.L.L.; Argente, M.-J. Inflammatory correlated response in two lines of rabbit selected divergently for litter size environmental variability. Animals 2020, 10, 1540. [CrossRef] [PubMed]

19. Blasco, A. Bayesian Data Analysis for Animal Scientists; Springer: Cham, Switzerland, 2017; ISBN 978-3-319-54273-7.

20. Khandoker, M.A.M.Y.; Tsujii, H.; Karasawa, D. A kinetics study of fatty acid composition of embryos, oviductal and uterine fluids in the rabbit. Asian-Australas. J. Anim. Sci. 1998, 11, 60-64. [CrossRef]

21. Kehl, S.J.; Carlson, J.C. Assessment of the luteolytic potency of various prostaglandins in the pseudopregnant rabbit. Reproduction 1981, 62, 117-122. [CrossRef]

22. García, M.L. Embryo manipulation techniques in the rabbit. In New Insights into Theriogenology, 1st ed.; Payan-Carreira, R., Ed.; IntechOpen: London, UK, 2018; pp. 113-133. [CrossRef]

23. Schindler, M.; Pendzialek, S.M.; Grybel, K.; Seeling, T.; Santos, A.N. Metabolic profiling in blastocoel fluid and blood plasma of diabetic rabbits. Int. J. Mol. Sci. 2020, 21, 919. [CrossRef] [PubMed]

24. Zarezadeh, R.; Mehdizadeh, A.; Leroy, J.L.; Nouri, M.; Fayezi, S.; Darabi, M. Action mechanisms of n-3 polyunsaturated fatty acids on the oocyte maturation and developmental competence: Potential advantages and disadvantages. J. Cell. Physiol. 2019, 234, 1016-1029. [CrossRef] [PubMed]

25. Kim, J.Y.; Kinoshita, M.; Ohnishi, M.; Fukui, Y. Lipid and fatty acid analysis of fresh and frozen-thawed immature and in vitro matured bovine oocytes. Reproduction 2001, 122, 131-138. [CrossRef] [PubMed]

26. Khandoker, M.A.M.Y.; Tsujii, H.; Karasawa, D. Fatty acid composition of blood serum, oocytes, embryos and reproductive tract fluids of rat and comparison with BSA. Anim. Sci. Technol. 1997, 68, 1070-1074. [CrossRef]

27. Tsujii, H.; Matsuoka, Y.; Obata, R.; Hossain, M.S.; Takagi, Y. Fatty acid composition of lipids in day 7-13 blastocysts, serum and uterine fluid of rabbits. Reprod. Med. Biol. 2009, 8, 107-112. [CrossRef]

28. Murakami, K.; Chan, S.Y.; Routtenberg, A. Protein kinase $C$ activation by cis-fatty acid in the absence of Ca2+ and phospholipids. J. Biol. Chem. 1986, 261, 15424-15429. [CrossRef]

29. Nishizuka, Y. The molecular heterogeneity of protein kinase C and its implications for cellular regulation. Nature 1988, 334, 661-665. [CrossRef]

30. Rodríguez, M.; Rebollar, P.G.; Mattioli, S.; Castellini, C. n-3 PUFA sources (precursor/products): A review of current knowledge on rabbit. Animals 2019, 9, 806. [CrossRef]

31. Rebollar, P.; García-García, R.; Arias-Álvarez, M.; Millán, P.; Rey, A.; Rodríguez, M.; Formoso-Rafferty, N.; de la Riva, S.; Masdeu, M.; Lorenzo, P. Reproductive long-term effects, endocrine response and fatty acid profile of rabbit does fed diets supplemented with n-3 fatty acids. Anim. Reprod. Sci. 2014, 146, 202-209. [CrossRef]

32. García, M.; Blasco, A.; Argente, M. Embryologic changes in rabbit lines selected for litter size variability. Theriogenology 2016, 86, 1247-1250. [CrossRef]

33. Hunter, M.; Robinson, R.; Mann, G.; Webb, R. Endocrine and paracrine control of follicular development and ovulation rate in farm species. Anim. Reprod. Sci. 2004, 82, 461-477. [CrossRef] [PubMed]

34. Jeffcoat, R. The biosynthesis of unsaturated fatty acids and its control in mammalian liver. Essays Biochem. 1979, 15, 1-36. [PubMed] 